\title{
Temperature Preference Responses of Some Aquatic, Cave-adapted Crustace:ans from Central Texas and Northeastern México*
}

\author{
by \\ William R. ELLIOTT** and Robert W. MITCHELL***
}

\section{INTRODUCTION}

The purpose of this study was to determine the preference responses of five species of aquatic, cave-adapted crustaceans in a temperature gradient. We studied two species of gammarid amphipods, Stygonectes hadenoecus Holsinger and S. russelli Holsinger, and three species of isopods, an asellid, Asellus reddelli Steeves, and two cirolanids, Cirolanides texensis Benedict and Speocirolana bolivari (Rioja). The first four species are from Texas, the last from Tamaulipas, México. The specific objectives of the study were to compare the temperature preference responses of these five species with those reported for other troglobites, and to speculate on the significance of the presence or lack of temperature discrimination in aquatic troglobites.

Relatively few studies on temperature-related behavior of cavernicoles have been done. Szymczkowsky (1953) reported an activity optimum of $6^{\circ}-8^{\circ} \mathrm{C}$ for the troglophile spider, Meta menardi, but no preference data were gathered.

Edwards (1971) studied the temperature and relative humidity preferences of Cryptocellus pelaezi, a troglophile ricinuleid (Arachnida) from México. He found that this species preferred temperatures of $23.5^{\circ}-28^{\circ} \mathrm{C}$, corresponding closely to the temperature of Cueva de la Florida from which the specimens were collected.

Two studies have dealt with the temperature preferences of terrestrial troglobites. Mitchell (1971) reported that Rhadine subterranea, a carabid beetle from Central Texas, prefers temperatures cooler than its habitat in summer and prefers cave temperature $\left(20^{\circ} \mathrm{C}\right)$ in winter. Mitchell suggested that this seasonal change of temperature preference serves to restrict the beetles to the cave except during that time when their chances for survival on the surface would seem best. Bull and Mitchell (1972) found that two troglobite millipedes from Central Texas, Cambala speobia and Speodesmus bicornourus, prefer temperatures between $15^{\circ}$ and $26.5^{\circ} \mathrm{C}$. However, $C$. speobia is more selective of relative humidities at or approaching saturation and of temperatures closely corresponding to that of caves which it inhabits than is $S$. bicornourus which is less tolerant of elevated

* Assisted by a Grant in Support of Research to Mr. Elliott from the Theodore Roosevelt Memorial Fund of the American Museum of Natural History. We also acknowledge the assistance of the Graduate School, Texas Tech University.

** Department of Biology, Texas Tech University, Lubbock, Texas.

*** Department of Biology and The Museum, Texas Tech University, Lubbock, Texas. 
temperatures and reduced relative humidities. Bull and Mitchell suggested that $S$. bicornourus is an older troglobite than C. speobia because it is less responsive and less tolerant to environmental variations and has a distribution which indicates that its surface ancestor colonized caves much earlier than that of $C$. speobia.

Thinès $(1958,1969)$ observed the behavior of Caecobarbus geertsi, a troglobite cyprinid fish, in a natural temperature-light gradient inside the entrance of Kavuaya Cave in the Congo. Temperature preference behavior was not evident until night, when the forty-three individuals (twenty-nine young and fourteen adults) remained 5 to $7.5 \mathrm{~m}$ inside the entrance at a temperature of $21.8^{\circ}-22.8^{\circ} \mathrm{C}$. During the day, the young were distributed throughout the light gradient, but the adults apparently responded to the light and remained in the interior of the cave.

Two laboratory studies have dealt'with temperature preferences of aquatic troglobites. Mitchell (in press) found that the Central Texas cave planarian, Sphalloplana zeschi, from Zesch Ranch Cave, Mason County, has a temperature preferendum of $17^{\circ}-24^{\circ} \mathrm{C}$ in a gradient of $15^{\circ}-30^{\circ} \mathrm{C}$, but that it is not very efficient at sensing and avoiding the extremes of the gradient, which are lethal to it. This planarian inhabits water of $21^{\circ}-21.5^{\circ} \mathrm{C}$. Mitchell concluded that S.zeschi is a more recent troglobite than $S$. percoeca (a northern and eastern troglobite in the United States, studied by Buchanan, 1936) because it can withstand moderate exposure to light, exhibits negative phototaxis and rheotaxis, rights itself rapidly, and has a well-defined temperature preferendum. In contrast, $S$. percoeca is intolerant to sunlight, displays no oriented movements when exposed to light or moving water, and takes longer to right itself. These characters can probably be ascribed to its greater degree of cave-adaptation. Unfortunately, the temperature preference responses of $S$. percoeca are unknown.

Johnson (1967) investigated four closely related populations of blind characin fishes, genus Astyanax, and their surface ancestor, A. mexicanus, from México. He reported a preferendum of $23^{\circ}-30^{\circ} \mathrm{C}$ for all the populations he studied. These cave fishes inhabit waters of $21^{\circ}-25.5^{\circ} \mathrm{C}$.

Thus, all of the troglobite species mentioned above appear to have fairly well-defined temperature preferenda. The results for the aquatic species would seem to refute the hypothesis of Mitchell (1971) that troglobites which are imprisoned within caves should lose their ability to respond to variations in temperature, light, and relative humidity because of the relative constancy of the cave environment. Mitchell stated, "I would offer this hypothesis as appropriate only for those troglobites which are physically imprisoned in their subterranean habitats. Such troglobites would be primarily those aquatic species living in subterranean water systems which lack navigable connections with epigeal waters." This hypothesis would apply to cave-dwelling Astyanax and S. zeschi because of the nature of the caves they inhabit. Regarding troglobites which are not imprisoned, he further stated, "I could, then, propose as a second general hypothesis that terrestrial troglobites and some aquatic ones possess a complex of behavioral responses which operate to restrict them in their cave environment." 


\section{HABITATS OF THE SPECIES STUDIED}

We only studied aquatic populations which are effectively imprisoned in their respective cave habitats. To demonstrate the isolation of these populations from the epigeum, the cave habitats are described below.

Zesch Ranch Cave is located about $5 \mathrm{~km}$ southwest of Mason, Mason County, Texas. This small cave (about $12 \times 18 \mathrm{~m}$ and about $9 \mathrm{~m}$ deep) is the only known locality for Sphalloplana zeschi Mitchell (1968) and one of fifteen known localities for Stygonectes russelli (Holsinger, 1966, 1967). The cave has a small pool at its west and deepest end, which has no direct connection to the epigeum, but which fluctuates in size and depth depending on the dryness of the surrounding area (Mitchell, in press). The cave has a pit entrance of sufficient depth $(5 \mathrm{~m})$ to imprison the aquatic fauna within the subterranean habitat.

Two collections of S.russelli were made in August and November, 1970. Water temperature varied from $21^{\circ}-21.5^{\circ} \mathrm{C}$. The pool has no direct communication with larger bodies of water and apparently is filled by the rise of lower-lying groundwater (Mitchell, in press).

Stygonectes russelli is placed in the balconis species group by Holsinger (1966, 1967) who thinks it is possible that this species is actually a group of very similar sibling species descended from a common, spring-dwelling ancestor which became extinct in Texas during the Pleistocene.

The Devil's Snkhole is a deep pit-cave located $11 \mathrm{~km}$ east-northeast of Rocksprings, Edwards County, Texas. It is the only known locality for Stygonectes hadenoecus and one of thirteen recorded localities for Cirolanides texensis (Fig. 1) (Holsinger, 1966, 1967; Reddell, 1965, 1970). A new locality for

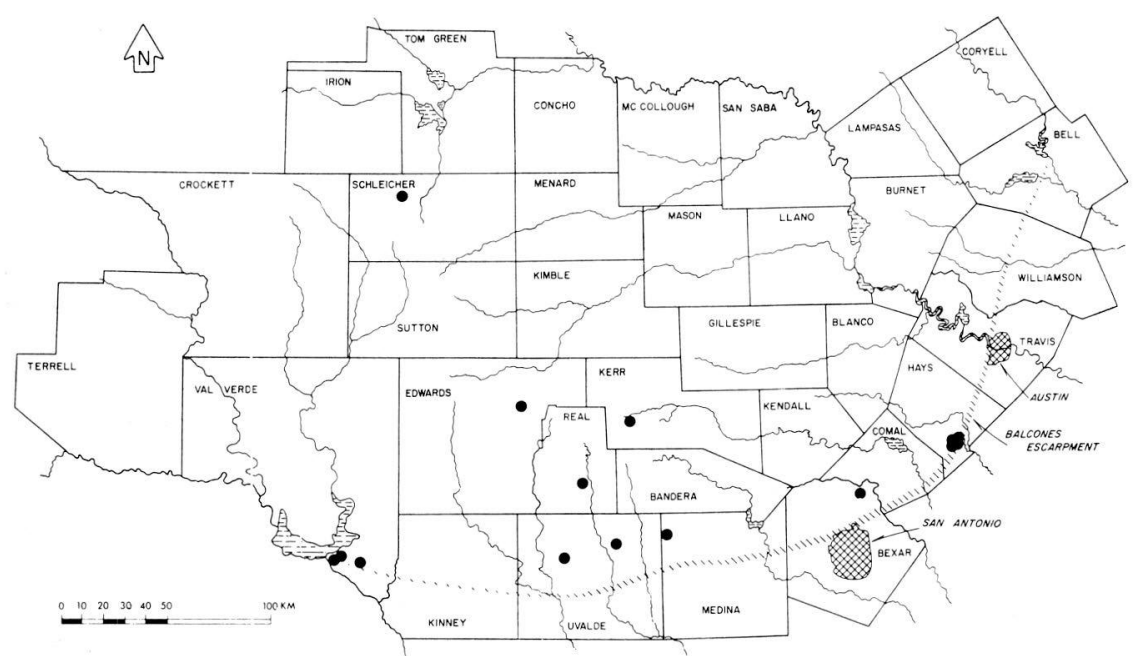

Fig. 1. The distribution of Cirolanides texensis in Central Texas.

A new record from Twin Pits Cave, Bexar County, is shown. 
C. texensis, Twin Pits Cave, Bexar Country, is shown in Fig. 1. The large pit entrance of Devil's Sinkhole has a vertical drop of $42 \mathrm{~m}$ to the top of a large talus mound. The talus slopes steeply to two lake rooms which are situated between its periphery and the dome-shaped ceiling, $95 \mathrm{~m}$ below the surface. No other entraces to the cave are known (Reddell and Smith, 1965). Aquatic animals are truly imprisoned within this cave.

Two collections of S.hadenoecus and C. texensis were made in October, 1970, and January, 1971. Stygonectes hadenoecus was found only in the smaller of the lakes. This lake is floored with guano from an overhanging colony of Mexican freetail bat, Tadarida brasiliensis mexicana. Stygonectes hadenoecus is seasonally abundant in both lakes (Reddell, 1970), presumably because of the declining abundance of bats and fresh guano during winter. Cirolanides texensis was abundant in the larger lake but rare in the smaller lake in both October and January; at times it is abundant in the small lake. The larger lake is much deeper and probably communicates with the regional groundwater. Divers have reached depths of 12 to $24 \mathrm{~m}$ (Reddell and Smith, 1965). Both lakes varied from $18^{\circ} \mathrm{C}$ in October to $17^{\circ} \mathrm{C}$ in January.

Stygonectes hadenoecus was tentatively placed in its own species group by Holsinger $(1966,1967)$ who was undecided as to whether it was an ancient offshoot of the flagellatus group or a member of a distinct lineage. The former is unlikely because caves far from the Balcones Fault Zone (such as Devil's Sinkhole) were available for colonization later than Fault Zone caves, and the flagellatus species are strictly Fault Zone cave-dwellers, indicating an early colonization time for their ancestor(s). Also, as Holsinger emphasized, geological discontinuities between Edwards County and the Fault Zone preclude dispersal of subterranean, aquatic animals between the two areas. The wide distribution of $C$. texensis (Fig. 1) argues for a relatively recent colonization by its ancestor (Mitchell and Reddell, 1971).

Jack's Joint is located in Travis County about $40 \mathrm{~km}$ northwest of Austin. This small fissure-cave contains two amphipods, Stygonectes bifurcatus and $S$. russelli (Reddell, 1970) as well as an unrecorded population of the asellid isopod, Asellus reddelli Steeves, which we studied. The cave is about $43 \mathrm{~m}$ long and is almost horizontal. The floor gradually ascends stepwise by means of rimstone pools at the back. When first visited in September, 1970, water was flowing from the entrance of the cave and over a $3 \mathrm{~m}$ high drop about $2 \mathrm{~m}$ outside the entrance. Apparently the water flows only when heavy rains have seeped through joints in the approximately $10 \mathrm{~m}$ of overburden. The isopods were found about $30 \mathrm{~m}$ from the entrance in a relatively quiet, shallow pool. Specimens were collected on the first trip and again in February, 1971. In February no water was flowing from the cave, and the pool was $19^{\circ} \mathrm{C}$. The September temperature was not taken but was probably lower than $19^{\circ} \mathrm{C}$ due to cool weather conditions.

This species is known from only four other Fault Zone caves (Reddell, 1970). In effect, the Jack's Joint population is isolated even when the water flows because of the precipice outside the entrance. Those animals which might be washed out would not be able to return and would be lost to the gene pool. There would seem 
to be little advantage for members of this population to have a well-developed temperature sense restricting them to the cave. The temperature of the water would not change appreciably in the short distance it flows between the entrance and "the point of no return". This isopod may be limited to the cave by means of positive rheotaxy or negative phototaxy.

Grutas de Quintero is a large cave located about $2 \mathrm{~km}$ south of the town of Quintero and about $11 \mathrm{~km}$ southwest of Ciudad Mante, Tamaulipas, México. It is the type locality of Speocirolana bolivari, a large cirolanid isopod which we used in this study. This species is known from two other localities in the Sierra Madre Oriental (J. Reddell, pers. comm.). The cave also contains Speocirolana pelaezi, a common cave species throughout the Sierra de El Abra in San Luis Potosí and Tamaulipas. Although these two species cohabit pools in the cave, they may readily be distinguished from each other: $S$. bolivari has much longer antennae, a more truncated telson, and is usually more translucent and elongated.

This cave has about $1200 \mathrm{~m}$ of explored passage, half of which has been surveyed (Russell and Raines, 1967). Speocirolana bolivari was collected from two pools, $240 \mathrm{~m}$ and $285 \mathrm{~m}$ from the entrance, in January, March, and May, 1971. In March, the temperature of the first, smaller pool was $23^{\circ} \mathrm{C}$ and the larger pool was $25^{\circ} \mathrm{C}$. We do not know what temperature fluctuations the water undergoes, but we have previously recorded $24^{\circ} \mathrm{C}$ in one of the pools. The cave does not take surface waters through its entrance but is a wet-weather resurgence for subterranean waters which drain from the cavernous Sierra de El Abra immediately to the West.

\section{MATERIALS AND METHODS}

The temperature gradient apparatus used in this study was essentially that described and illustrated in Bull and Mitchell (1972). Basically, it was an open aluminum channel, housed in an insulated case in which a temperature gradient could be established with electric strip heaters, a recirculating water-ethylene glycol solution, and much associated equipment. Fitting precisely into this channel was a Plexiglas insert $12010 \mathrm{~mm}$ long, $119 \mathrm{~mm}$ wide, and $60 \mathrm{~mm}$ deep (internal dimensions). The bottom of the insert was covered with about $3 \mathrm{~mm}$ of black obsidian gravel. Thirteen thermistor sensors were positioned at $10 \mathrm{~cm}$ intervals along the center of the inser: with their tips touching the gravel. These thermistor sensors served to delineate the insert into twelve areas such that the low and high temperatures for each area could be read on a multi-channel transitorized thermometer.

A gradient of $15^{\circ}-30^{\circ} \mathrm{C}$ was used for all five species studied; $S$. hadenoecus was also tested in a gradient of $10^{\circ}-30^{\circ} \mathrm{C}$. All species were tested in dechlorinated tapwater. The four Texas species were tested in $15 \mathrm{~mm}$ deep water. Speocirolana bolivari, being a larger animal, was tested in $20 \mathrm{~mm}$ deep water to insure that all individuals were completely immersed.

The same insert was used for the control runs. Some control data were gathered by allowing the entire apparatus to equilibrate with ambient temperature $\left(20^{\circ} \mathrm{C}\right)$ in 
a temperature control room. Other control data were gathered with the insert fitted into a separate wooden box with a $1.5 \mathrm{~mm}$ thick aluminum bottom beneath which were attached two electric heating belts equal in length to the insert. The heating belts were controlled by an Athena Model 51 proportional temperature controller actuated by a thermistor sensor located in the center of the insert. This permitted the desired control temperature to be established independently of ambient temperature.

It is more accurate to describe the gradient established in the water as a temperature-oxygen gradient. Oxygen tensions at the ends of the gradient were determined by the Alsterberg modification of the Winkler method (Am. Public Health Assoc., 1960). Water was extracted with a syringe from the bottom of the insert. At $10^{\circ} \mathrm{C}$ the oxygen tension was about $7.5 \mathrm{ppm}$, at $15^{\circ} \mathrm{C}$ it was about $7 \mathrm{ppm}$, and at $30^{\circ} \mathrm{C}$ it was about $5 \mathrm{ppm}$. No attempt was made to eliminate this oxygen gradient because one would expect different oxygen tensions at different water temperatures under natural conditions.

Specimens were collected with small dip nets or by hand and were transported to the laboratory in polyethylene containers filled with water from their respective habitats. These containers were placed in polystyrene foam coolers to minimize sharp temperature changes en route. The Texas species were kept at $20^{\circ} \mathrm{C}$ in the laboratory as was the January collection of $S$. bolivari. We later suspected that the latter species may have acclimated to this temperature, which is $3-5 \mathrm{C}^{\circ}$ cooler than its natural habitat. For this reason, the March and May collections of $S$. bolivari were kept at $24^{\circ} \mathrm{C}$ in a heated aquarium. All species were kept in darkness and infrequently fed pieces of crickets.

Before and after each experimental and control replicate the temperature at each thermistor sensor was recorded. Usually the temperature at each sensor varied no more than $\pm 0.5 \mathrm{C}^{\circ}$ in the experimental conditions. With $S$. bolivari the temperatures in the middle range of the gradient were occasionally upset as much as $\pm 1.0 \mathrm{C}^{\circ}$ by the end of the experimental replicate.

Forty-eight individuals of each species were tested in both gradient and control situations. In both experimental and control runs the animals were randomly introduced (with the use of a random numbers table) into the insert by area, facing the sides rather than the ends. The purpose of this was to avoid any positional or directional bias. The laboratory lights were then turned off, leaving the room in total darkness. After five minutes the number of animals in each area was counted by flashlight and recorded. Their positions were recorded every five minutes for two hours, yielding twenty-four observation periods for each replicate.

The two cirolanid species were each run in four replicates of twelve individuals. The other three species were run in six replicates of eight individuals each. Thus, for each species, there were 1152 observations made in both experimental and control situations. Stygonectes hadenoecus was run again in a gradient of $10^{\circ}-30^{\circ} \mathrm{C}$ because its responses in the $15^{\circ}-30^{\circ} \mathrm{C}$ gradient were difficult to interpret. The first experiment on $S$. bolivari was done with forty-eight individuals which had been kept at $20^{\circ} \mathrm{C}$ in the laboratory. Forty-eight other individuals, which were kept at $24^{\circ} \mathrm{C}$, were used for the control run at $24^{\circ} \mathrm{C}$ and for a second experiment. 
Experimental and control data for each species were compared by $2 \times 12$ contingency table analysis to determine whether they were significantly different. A computerized linear regression analysis (Sokal and Rohlf, 1969) was applied to each set of experimental and control data to determire if there was significant association of nurnbers of observations with areas of the gradient and if there were significant deviations of the data from a linear regression line. In three experiments in which the data did not fit a linear regression, a computerized stepwise polynomial regression analysis (Dixon, 1971) was employed to determine what degree of polynomial regression equation best fit the data. Fourth-degree polynomial equations were computed for each of the three experiments although we found that a quartic equation fit only one of the data sets the best and quadratic and cubic equations fit the other two the best.

\section{RESULTS}

The results of the experimental and control runs are presented as histograms (Figs. 2-6). In each histogram the ordinate represents the twelve areas of the insert and the temperature at each thermistor sensor (averaged over all the replicates). The abscissa represents the total number of observations recorded for each area.

Fig. 2 presents the results of the two experimental runs and the control results for Stygonectes hadenoecus. Inspection of the graph for Experiment $1\left(15^{\circ}-30^{\circ} \mathrm{C}\right)$ seems to indicate a preference for the cool end of the gradient and roughly increasing avoidance of warmer temperatures. One might conclude from this graph alone that this species prefers temperatures of $15^{\circ}-20.5^{\circ} \mathrm{C}(76 \%$ of total observations), perhaps being strongest between $15^{\circ}$ and $16.5^{\circ} \mathrm{C}(38 \%$ of total). This interpretation does not take into account the possibly large "end effect" which is evident in the control results. End effect, or edge effect, is the tendency for animals to concentrate at the boundaries on their enclosure, and the control data measure it. We also tested this species in a $10^{\circ}-30^{\circ} \mathrm{C}$ gradient (Experiment 2) to determine if the apparant preference in Experiment 1 was consistent. Inspection of the graph for Experiment 2 indicates that this species does not prefer temperatures of $15^{\circ}-20.5^{\circ} \mathrm{C}$, and that it has no well-defined temperature preferendum. It is probable that the large number of observations for area 1 in Experiment 1 was the result of end effect. It is probable that the lack of end effect in area 1 of Experiment 2 was the result of a slight avoidance of the cold end. Both experiments show that this species markedly avoids temperatures above $24^{\circ} \mathrm{C}$.

Contingency table analysis (Table 1 ) showed that each of the experimental data sets were different from the control data and from each other $(\mathrm{P}<.001)$. Linear regression analysis of the Experiment 1 data showed a significant linear relationship between areas of the gradient (independent variable) and numbers of observations (dependent variable) $(\mathrm{P}<.01)$. The y values (dependent variable) did not deviate significantly from the regression line $(\mathrm{P}>$. 05). Linear regression analysis of the Experiment 2 data showed no significant association of $\mathrm{x}$ and y values $(\mathrm{P}>.05)$ and there were no significant deviations from the linear regression line $(\mathrm{P}>.05)$. In the 
Table $1.2 \times 12$ Contingency table analyses of experimental-control and experimental-experimental data

$$
\text { Area of gradient chamber }
$$

$\begin{array}{llllllllllll}1 & 2 & 3 & 4 & 5 & 6 & 7 & 8 & 9 & 10 & 11 & 12\end{array}$

S. hadenoecus

$\begin{array}{lllllllllllll}\text { Experiment 1 } & 206 & 192 & 99 & 152 & 105 & 118 & 108 & 74 & 33 & 45 & 12 & 8\end{array}$ $\begin{array}{lllllllllllll}\text { Control } & 165 & 103 & 88 & 75 & 94 & 102 & 93 & 72 & 72 & 70 & 110 & 108\end{array}$ $\chi^{2} / 11$ d.f. $=245.92, \mathrm{P}<.001$

$\begin{array}{llllllllllll}1 & 2 & 3 & 4 & 5 & 6 & 7 & 8 & 9 & 10 & 11 & 12\end{array}$

S. hadenoecus

$\begin{array}{lllllllllllll}\text { Experiment } 2 & 88 & 112 & 90 & 91 & 119 & 113 & 159 & 91 & 155 & 101 & 33 & 0\end{array}$ $\begin{array}{lllllllllllll}\text { Control } & 165 & 103 & 88 & 75 & 94 & 102 & 93 & 72 & 72 & 70 & 110 & 108\end{array}$ $\chi^{2} / 11$ d.f. $=233.80, \mathrm{P}<.001$

$\begin{array}{llllllllllll}1 & 2 & 3 & 4 & 5 & 6 & 7 & 8 & 9 & 10 & 11 & 12\end{array}$

S. hadenoecus

$\begin{array}{lllllllllllll}\text { Experiment 1 } & 206 & 192 & 99 & 152 & 105 & 118 & 108 & 74 & 33 & 45 & 12 & 8\end{array}$ $\begin{array}{lrlllllllllll}\text { Experiment } 2 & 88 & 112 & 90 & 91 & 119 & 113 & 159 & 91 & 155 & 101 & 33 & 0\end{array}$ $\chi^{2} / 11$ d.f. $=215.08, \mathrm{P}<.001$

$\begin{array}{llllllllllll}1 & 2 & 3 & 4 & 5 & 6 & 7 & 8 & 9 & 10 & 11 & 12\end{array}$

S. russelli

$\begin{array}{lllllllllllll}\text { Experiment } & 145 & 59 & 65 & 79 & 107 & 132 & 101 & 88 & 104 & 90 & 103 & 79\end{array}$

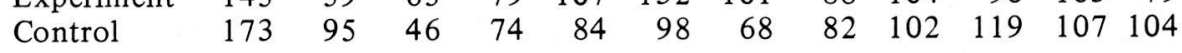
$\chi^{2} / 11$ d.f. $=36.28, \mathrm{P}<.001$

$\begin{array}{llllllllllll}1 & 2 & 3 & 4 & 5 & 6 & 7 & 8 & 9 & 10 & 11 & 12\end{array}$

Asellus sp.

$\begin{array}{lllllllllllll}\text { Experiment } & 133 & 86 & 86 & 94 & 117 & 120 & 87 & 91 & 106 & 98 & 84 & 50\end{array}$ $\begin{array}{lrrrrrrrrrrrr}\text { Control } & 111 & 74 & 98 & 92 & 112 & 78 & 101 & 100 & 65 & 70 & 69 & 182\end{array}$ $\chi^{2} / 11$ d.f. $=105.24, \mathrm{P}<.001$

$\begin{array}{llllllllllll}1 & 2 & 3 & 4 & 5 & 6 & 7 & 8 & 9 & 10 & 11 & 12\end{array}$

C. texensis

$\begin{array}{lllllllllllll}\text { Experiment } & 30 & 20 & 17 & 22 & 21 & 33 & 72 & 140 & 191 & 266 & 213 & 127\end{array}$ $\begin{array}{lrlllllllllll}\text { Control } & 127 & 83 & 87 & 82 & 93 & 53 & 58 & 61 & 109 & 82 & 144 & 173\end{array}$ $\chi^{2} / 11$ d.f. $=402.97, \mathrm{P}<.001$ 
Table $1 \quad$ Continued

Area of gradient chamber

$\begin{array}{llllllllllll}1 & 2 & 3 & 4 & 5 & 6 & 7 & 8 & 9 & 10 & 11 & 12\end{array}$

S. bolivari

$\begin{array}{llllllllllrrr}\text { Experiment } 1 & 179 & 76 & 72 & 59 & 93 & 65 & 61 & 64 & 75 & 132 & 149 & 127 \\ \text { Control } & 205 & 75 & 74 & 77 & 92 & 86 & 72 & 59 & 77 & 72 & 81 & 182\end{array}$
$\chi^{2} / 11$ d.f. $=55.73, \mathrm{P}<.001$

$\begin{array}{llllllllllll}1 & 2 & 3 & 4 & 5 & 6 & 7 & 8 & 9 & 10 & 11 & 12\end{array}$

S. bolivari

$\begin{array}{lrlllllllrrrr}\text { Experiment } 2 & 170 & 69 & 72 & 59 & 60 & 65 & 69 & 71 & 104 & 140 & 155 & 118 \\ \text { Control } & 205 & 75 & 74 & 77 & 92 & 86 & 72 & 59 & 77 & 72 & 81 & 182\end{array}$

$\chi^{2} / 11$ d.f. $=79.45, \underline{\mathrm{P}}<.001$

$\begin{array}{llllllllllll}1 & 2 & 3 & 4 & 5 & 6 & 7 & 8 & 9 & 10 & 11 & 12\end{array}$

\section{S. bolivari}

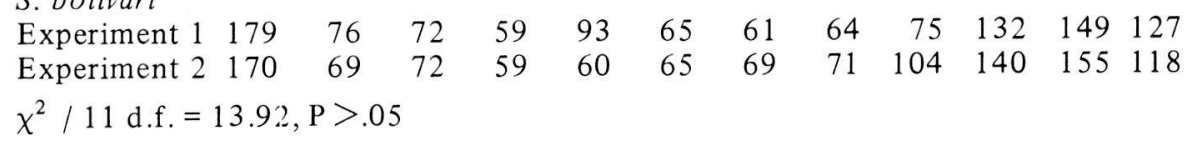

control, $x$ and $y$ values were not significantly associated $(P>.05)$ but there were significant deviaticns $(\mathrm{P}<.01)$, indicating curvilinearity, as can be seen from the graph. The conflicting results from the regression analyses on the two experiments indicate to us that $S$. hadenoecus behaves erratically in a temperature gradient and has no discernible thermal preferendum. It does, though, appear to avoid temperatures above: $24^{\circ} \mathrm{C}$.

Fig. 3 presents the experimental and control results for Stygonectes russelli. This species has no apparent thermal preferendum in a $15^{\circ}-30^{\circ} \mathrm{C}$ gradient.

Contingency table analysis (Table 1 ) showed a significant difference between the experimental and control data $(\mathrm{P}<.001)$. However, linear regression analysis showed there was no significant association of $\mathrm{x}$ and $\mathrm{y}$ values in either the experiment or control $(\mathrm{P}>$.05). The $\mathrm{y}$ values in the experiment did not deviate significantly from the regression line $(\mathrm{P}>.05)$, but the $y$ values in the control $\operatorname{did}(\mathrm{P}<.01)$. It may appear from the graph for the experiment that this species exhibited some response to temperatures of $18.5^{\circ}-21.5^{\circ} \mathrm{C}$. However, this small peak is only $30 \%$ of the total number of observations and does not demonstrate a temperature preference response. During the experiment, we made 55 observations on 41 different occasions of an animal or several animals clinging to the thermistor sensor at the cold end. There is a little doubt that in many instances these were the same animals from one observation period to the next. In one experimental replicate, there was at least one 

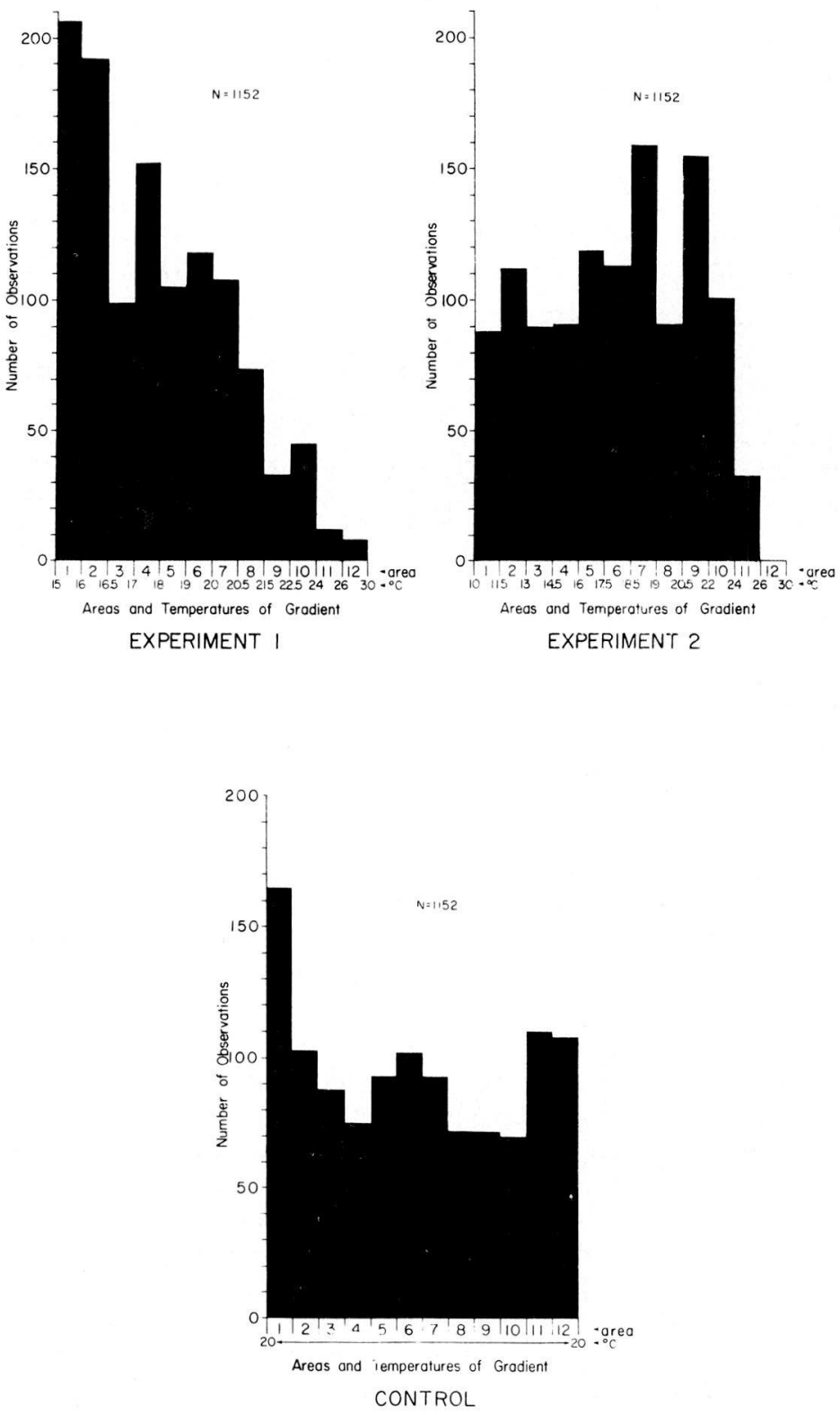

Fig. 2. Experimental and control results for Stygonectes hadenoecus. 


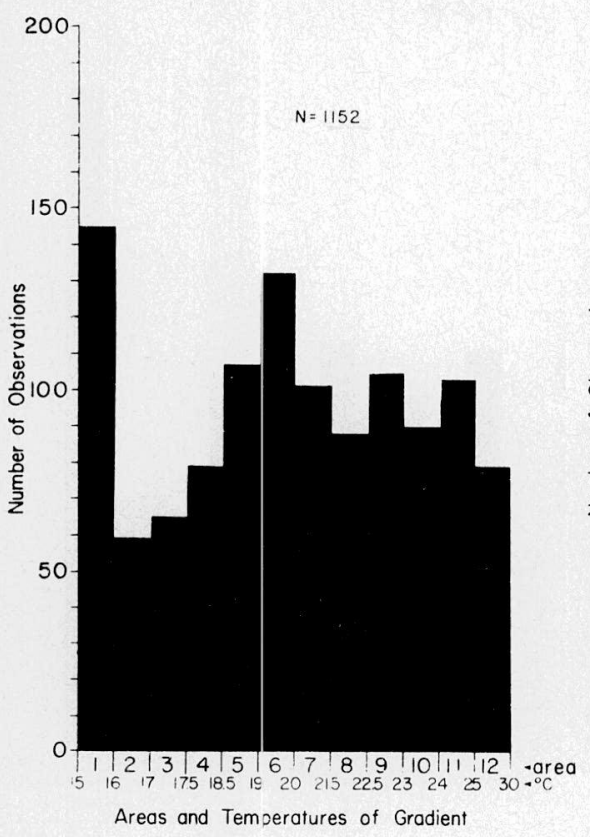

EXPE:RIMENT

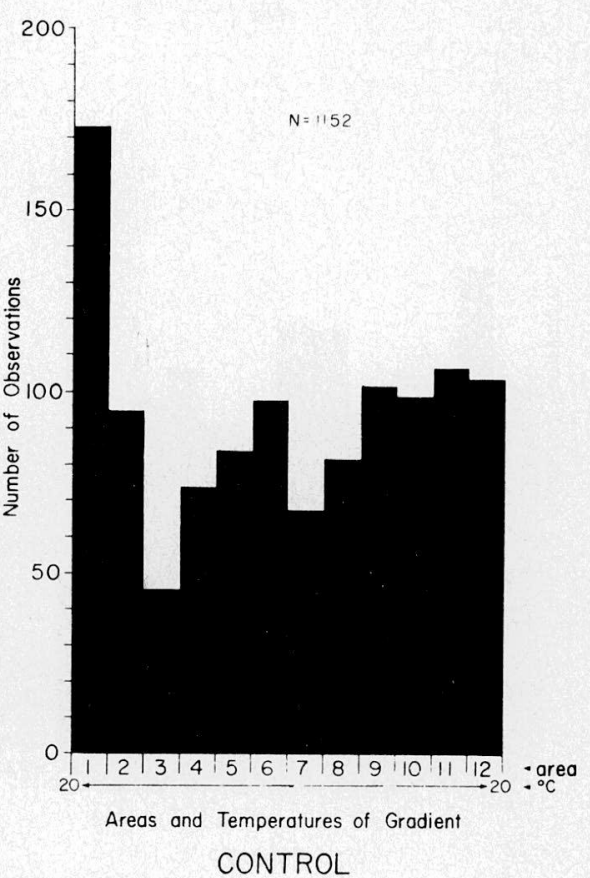

Fig. 3. Experimental and control results for Stygonectes russelli.

animal clinging to the sensor at the cold end for 20 consecutive observations. This may have been the same individual each time. These animals were probably "coldtrapped", or lethargic and immobile from the cold. Cold-trapping in this species would lend support to the idea that this species is rather insensitive to temperature differences.

Fig. 4 presents the experimental and control results for Asellus reddelli. This species had no apparent thermal preferendum in a $15^{\circ}-30^{\circ} \mathrm{C}$ gradient.

Contingency table analysis (Table 1) of the experimental and control data showed a significant difference between the two $(\mathrm{P}<.001)$. Linear regression analysis showed no significant association of $x$ and $y$ values in either the experimental or control data $(\mathrm{P}>.05)$ and no significant deviations in the experimental data $(\mathrm{P}>.05)$. The $y$ values for the control deviated significantly $(\mathrm{P}<.05)$. Asellus reddelli may avoid temperatures above $25.5^{\circ} \mathrm{C}$ slightly, but has no other perceivable temperature response.

Fig. 5 presents the results of the two experiments and the control for Speocirolana bolivari. Experiment 1 was done on animals which had been kept in the laboratory at $20^{\circ} \mathrm{C}$ and Experiment 2 with animals kept at $24^{\circ} \mathrm{C}$. 

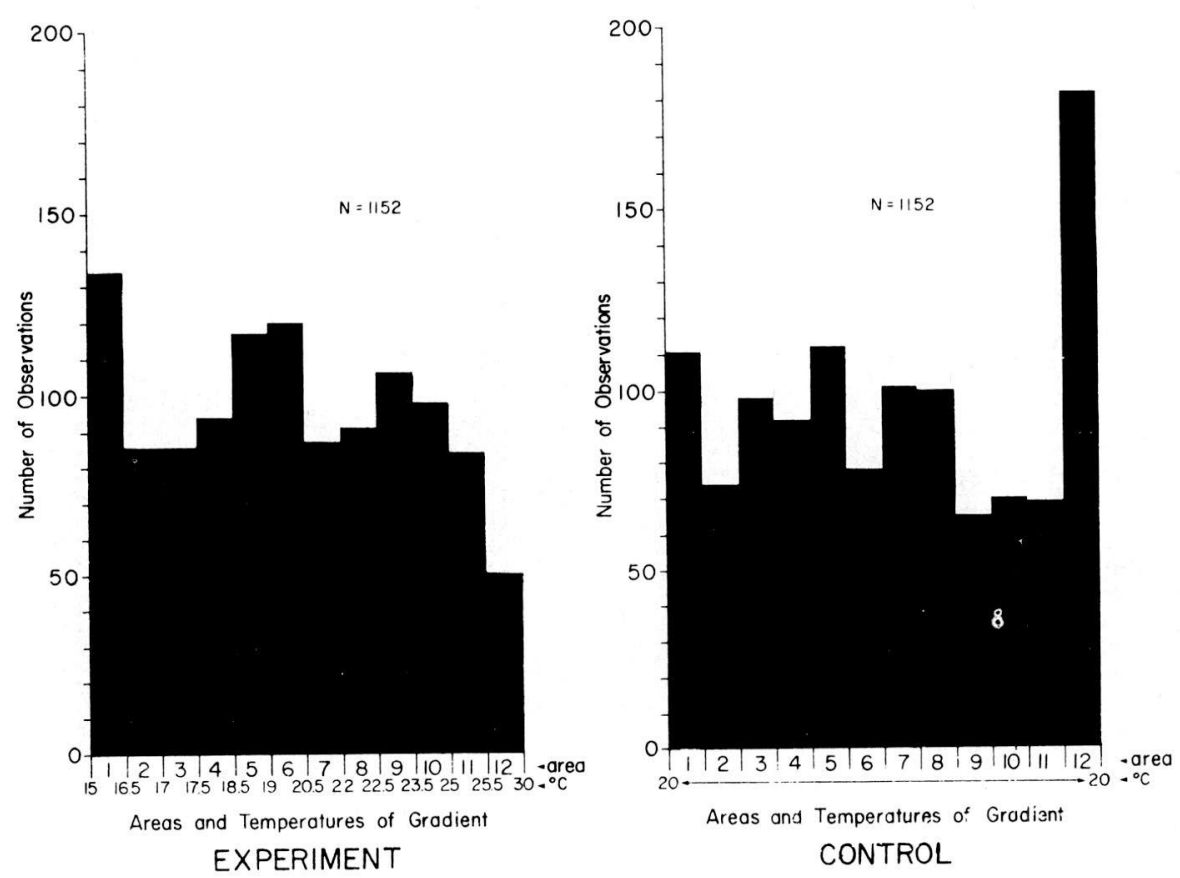

Fig. 4. Experimental and control results for Asellus reddelli.

Contingency table analysis (Table 1) showed no significant difference between the two experiments $(\mathrm{P}>.05)$. Both experiments were significantly different from the control $(\mathrm{P}<.001)$. Thus, it appears that this species did not acclimate its temperature preference to lower temperatures $\left(20^{\circ} \mathrm{C}\right)$ in the laboratory. However, inspection of the graph for Experiment 1 reveals a slight peak of occurrences in area 5 , between $19^{\circ}$ and $19.5^{\circ} \mathrm{C}$. It is possible that a few individuals acclimated to laboratory temperature and lingered in this area. However, this is only conjecture.

Linear regression analysis for $S$. bolivari showed no significant association of $\mathrm{x}$ and $y$ values for either of the experiments or for the control $(\mathrm{P}>.05)$. However, all three had significant deviations $(\mathrm{P}<.01)$. Stepwise polynomial regression analysis to degree four was applied to both sets of experimental data. A quadratic polynomial regression was found to have the best fit for the Experiment 1 data which showed significant curvilinearity $(\mathrm{P}<.025)$. The equation described $63 \%$ of the variation. For the Experiment 2 data, a cubic polynomial regression was found to have the best fit and showed significant curvilinearity $(\mathrm{P}<.005)$. The equation described $84 \%$ of the variation. Thus, it appears that this species has a rather weak but discernible temperature preferendum, about $20^{\circ}-30^{\circ} \mathrm{C}$ (58\% of occurrences in Experiment 1 , 


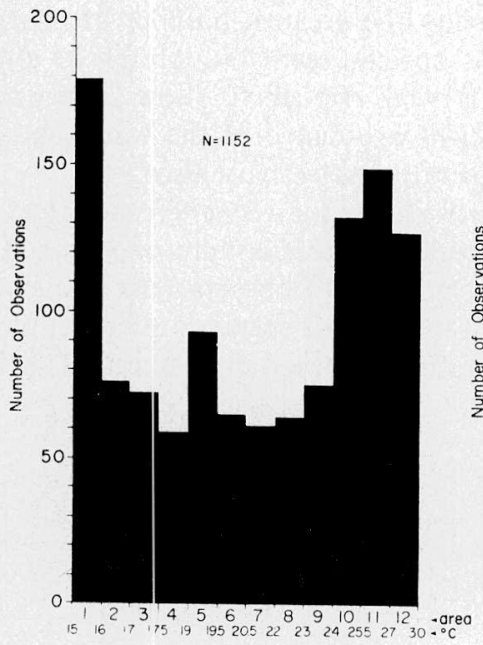

Areas and Temperatures of Gradient

EXPERIMENT ।

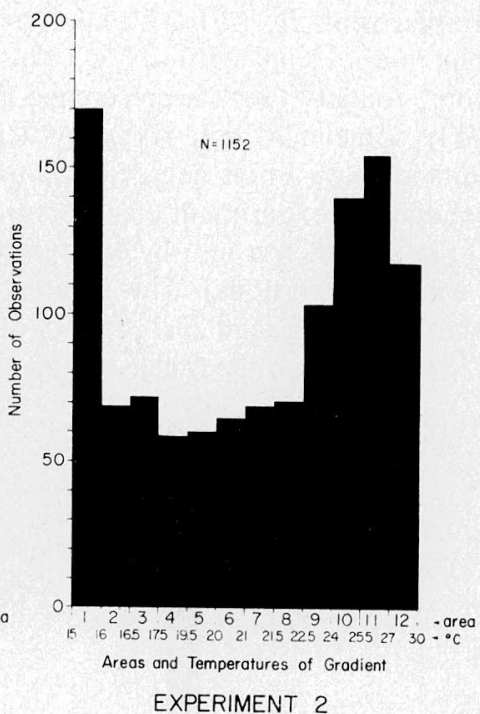

EXPERIMENT 2

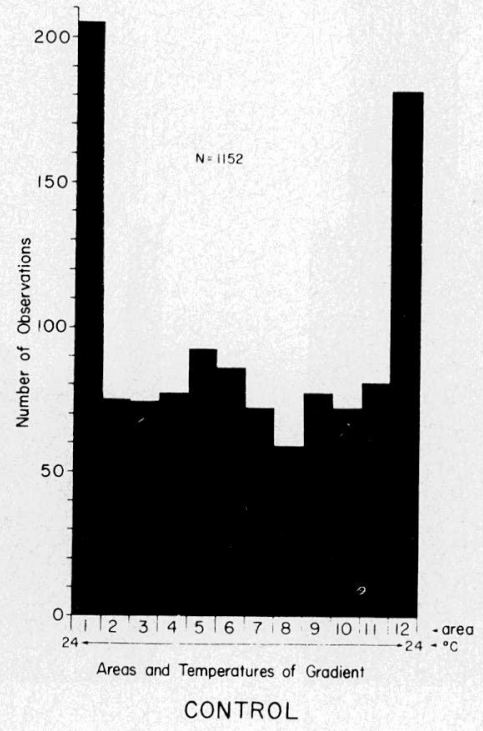

Fig. 5. Experimental and control results for Speocirolana bolivari. 
$63 \%$ in Experiment 2). In both experiments the greatest number of observations occurred in area 11 at $25.5^{\circ}-27^{\circ} \mathrm{C}$. This species seems to prefer its own cave temperature, roughly, yet its preference is weak enough to allow some end effect and possibly some mild cold-trapping. Slight avoidance of the warm end in both experiments indicates some degree of temperature selectivity also.

Fig. 6 shows the experimental and control results for Cirolanides texensis. As can be seen, this species has an obvious temperature preferendum of about $20^{\circ}-30^{\circ} \mathrm{C}$ ( $88 \%$ of total observations). The greatest number of observations in a single area occurred between $22.5^{\circ}$ and $23.5^{\circ} \mathrm{C}$ ( $23 \%$ of total). This species prefers temperatures 2 to $12 \mathrm{C}^{\circ}$ warmer than the highest temperature recorded in its habitat $\left(18^{\circ} \mathrm{C}\right)$.
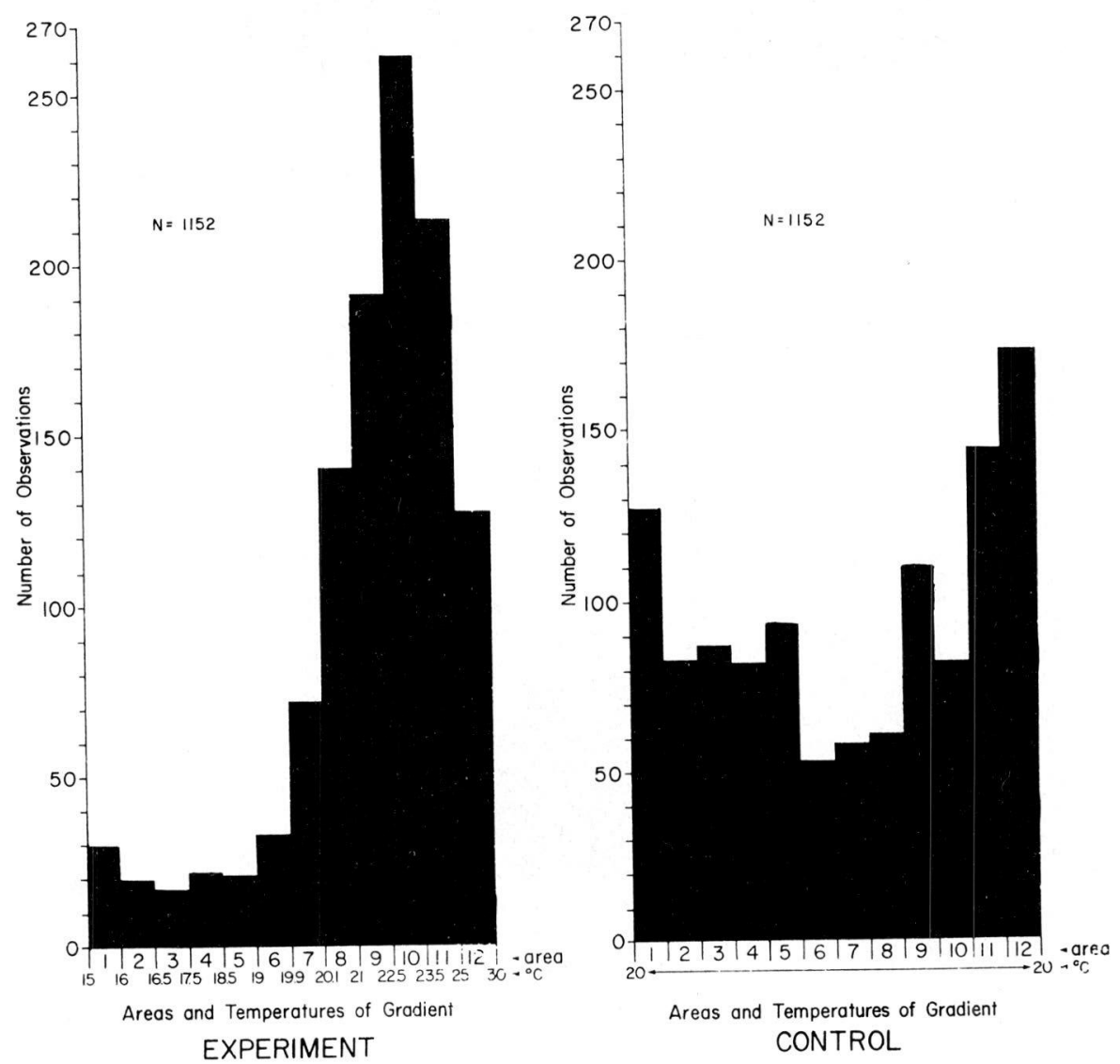

Fig. 6. Experimental and control results for Cirolanides texensis. 
Contingency table analysis (Table 1) indicated a significant difference between the experiment and control $(\mathrm{P}<.001)$. Linear regression analyses of the experimental and control data showed a significant association of $x$ and $y$ values in the experiment $(\mathrm{P}<.01)$, none in the control $(\mathrm{P}>.05)$, and significant deviations for both $(\mathrm{P}<.01$ for experiment, $\mathrm{P}<.05$ for control). Stepwise polynomial regression analysis of the experimental data resulted in a quartic equation of very close fit ( $98 \%$ of variation explained). The data were highly significantly curvilinear $(\mathrm{P}<.001)$. Almost $68 \%$ of the variation was described by the linear term alone, reflecting the sharpness of the curve's peak. There can be little doubt that this species has a very well-defined temperature preferendum.

\section{DISCUSSION}

Of the five species studied, three have no discernible, or at best, very weak temperature preferenda, one has a weak preferendum, and one has a strong, well-defined preferendum. The three species with no discernible preferenda probably responded somewhat to both extremes of the gradient. This is borne out by the fact that their responses were linear whereas the control data were curvilinear, and the fact that the experiments were significantly different from the controls. The differences may have resulted from avoidance responses, coldtrapping, responses to the oxygen gradient, or a combination of these phenomena.

There is a possibility that some of the species had temperature responses which were obscured by their responses to the oxygen gradient. If this were so, it would only show that their temperature responses were relatively weak. It appears that the temperature response of $C$. texensis was very strong because it is difficult to imagine why this species would prefer the oxygen-poorer end of the gradient. It might be objected that the large end effect at the cold end in Experiment 1 on $S$. hadenoecus, and in both experiments on $S$. bolivari, was enhanced by a response to the oxygen gradient. However, Experiment 2 on $S$. hadenoecus demonstrated no preference for the colder, oxygen-richer end of the gradient. The end effect at the cold end in both experiments on $S$. bolivari was not as large as in the control, which presumably had no oxygen gradient.

The avoidance of two extremes demarcates a preferendum, but such a demarcation was possible only for the two cirolanid species. Even though $S$. hadenoecus and A.reddelli had few occurrences in the warm end and relatively great numbers of occurrences in the cold end, these are not neccesarily best explained as taxes. These may have only been kineses (cold-trapping in the cold end, and a rise in body temperature, metabolic rate, and locomotor rate in the warm end). Although these species may have responded to the extremes of such gradients as $10^{\circ}-30^{\circ} \mathrm{C}$ or $15^{\circ}-30^{\circ} \mathrm{C}$, these extremes probably never occur in the caves they inhabit. Therefore, their responses to such extremes are unimportant to them in their natural habitats.

Two general explanations for the results of this study may be suggested. First, assuming that each of the species is isolated in a subterranean habitat, the 
temperature fluctuations of each habitat may be more important than the degree of cave-adaptation in determining the extent to which each species exhibits a temperature preferendum. If these species are imprinted with a temperature sense, the caves having the greatest temperature fluctuations may then have the aquatic species with the least temperature specificity. However, this would not explain why the Devil's Sinkhole contains a species with a narrow preferendum $(C$. texensis $)$ and another with no discernible preferendum (S.hadenoecus). Also, the water temperature in Zesch Ranch Cave varies little, yet this cave is inhabited by $S$. russelli, which has no discernible preferendum, and Sphalloplana zeschi, which has a well-defined preferendum.

Mitchell's (1971) hypothesis seems to better explain the behavior of these species. The three species with no discernible preferenda have probably lost their abilities to perceive and respond to spatial differences in temperature because temperature is relatively constant in their habitats. The loss of thermoreceptors and temperature-related behavioral traits would be analogous to the loss of eyes and pigment, structures which are non-adaptive in cave animals. We could hypothesize that species which have only entered the early stages of troglobitism, even though imprisoned in the hypogeum, may retain their temperature preference responses. This would apply to both "recent" species and those which are older but which have undergone slow rates of adaptation.

The explanation for the pronounced temperature preferendum of C.texensis may lie in its geographic origin and ancestry. The Cirolaninae are predominantly marine, all but one of the North American freshwater species being cave-dwellers. Of the eleven North American cavernicole species, nine are from tropical or semi-tropical areas. Cave cirolanids are commonly referred to as "marine relicts" because their distributions are easily explained, in some cases, as a result of direct colonization of subterranean waters by marine ancestors. Bolivar y Pieltain (1950), Vandel (1964), and Bowman (1964) have discussed the origins of cave cirolanids. Vandel said, "Les Cirolanides hypogés sont si voisins des formes marines que l'on ne saurait douter qu'ils en dérivent directement. Mais ont-ils passé par un stade épigé et dulçaquicole? C'est ce à quoi nous ne saurions répondre actuellement." However, Mitchell and Reddell (1971) said, "C. texensis, like the stygonectid amphipods, as suggested by Holsinger (1967), was probably derived from its marine stock through the intermediacy of a freshwater ancestor, since marine waters receded from Central Texas prior to the time of cave accessibility and never encroached upon the area subsequently." Bowman (1964) discussed the possibility of Antrolana lira having been derived from a freshwater ancestor, but was undecided as to whether this was an adequate explanation of the species' distribution (it is known only from one cave in Virginia). In view of the temperature preferendum of C.texensis, and the species' wide distribution in Central Texas, we suggest that this species had a rather recent freshwater ancestor. We also suggest that its ancestor was of southern derivation since the species prefers temperatures more characteristic of tropical waters than temperate waters. Colonization may have occurred in Recent times during the warming trend following the last glaciation.

Speocirolana bolivari is probably the descendant of a marine species which 
directly colonized caves along the front of the Sierra de El Abra, part of a massive Cretaceous platform. Uplift of the Sierra de El Abra occurred in early Tertiary times and was accompanied by recession of the sea from the area (Mitchell, 1969). Caves may have been available for colonization as early as Cretaceous times (Mitchell, Russell, and Elliott, in press). Thus, this species may have been a cavedweller for a long period of time, yet it still retains a temperature preferendum. This may be the result of a slow rate of cave-adaptation. Mitchell (1969) has hypothesized than the rate of cave-adaptation in the tropics may be slower than in temperate or highland areas. Energy economization, being at a premium in caves of low food input, may accelerate the selective loss of non-adaptive, energy consuming structures and traits. Tropical and semi-tropical areas, with their relatively greater food abundance both on the surface and in caves, may have cave species which evolve troglobite features at a slower rate than temperate or highland cave species.

In conclusion, it would seem that a very constant temperature, through time, may not be necessary for truly imprisoned troglobites to eventually lose their responses to spatial temperature differences. We refer to aquatic troglobites which would have access to neither the epigeum nor deeper groundwater. If a cave were so formed that the water in it were shallow, and all of it underwent the same temperature fluctuations, there would still be no advantage in being able to sense and respond to temperature changes. An example of this would be Jack's Joint. Asellus reddelli is imprisoned in this cave by the drop outside the entrance and probably has no access to lower-lying groundwater because of the way the cave floor rises toward the back. Water which comes indirectly from the surface may undergo temperature fluctuations depending on the weather. Since the cave is small, the water flowing through it would probably be of a uniform temperature throughout, and temperature changes would be fairly uniform throughout the cave. The aquatic fauna would have no "choice" as far as temperature is concerned. It is likely that similar situations exist elsewhere, such as springs and interstitial habitats, so that one might expect a loss of temperature selectivity for animals imprisoned in those habitats.

\section{ACKNOWLEDGEMENTS}

The authors wish to thank Mr. Clarence Whitworth and Mr. Kurt Zesch for allowing us to work in their caves (the Devil's Sinkhole and Zesch Ranch Cave) and Mr. Greg Passmore and Mr. Glenn Darilek for new locality data and specimens of Cirolanides texensis. We are indebted to Dr. Laurence Fleming for identifying the specimens of Asellus reddelli, and to Dr. William Atchley, Mr. Mel Brownfield, Dr. Walter Conley, Mr. Jerry Cooke, Mr. Ronnie Fieseler, Mr. James Reddell, Mr. William Russell, Mr. Jon Vinson, and Mrs. Suzanne Wiley for their assistance. 


\section{SUMMARY}

The temperature preference responses of five species of troglobite crustaceans were studied in a $15^{\circ}-30^{\circ} \mathrm{C}$ gradient. Stygonectes hadenoecus, S. musselli, and Asellus reddelli had no discernible temperature preferenda. Speocirolana bolivari had a weak preference for $20^{\circ}-30^{\circ} \mathrm{C}$. Cirolanides texensis had a pronounced preference for $20^{\circ}-30^{\circ} \mathrm{C}$, temperatures much warmer than that of its habitat. The lack of temperature preferenda in three species agrees with the hypothesis that imprisoned troglobites tend to lose responses to those environmental variables which are constant in caves. $S$. bolivari may retain its temperature selectivity because of a slow rate of cave-adaptation. It is hypothesized that $C$. texensis is recently descended from a tropical, epigean, freshwater ancestor.

\section{RESUME}

Le préférendum de température de cinq espèces troglobies de Crustacés a été étudié dans un intervalle compris entre $15^{\circ}$ et $30^{\circ}$. Stygonectes hadenoecus, S. russelli et Asellus reddelli ne présentent aucun préférendum de température notable. Speocirolana bolivari montre une légère préférence pour les températures de $20^{\circ}$ à $30^{\circ}$. Cirolanides texensis possède un préférendum très marqué pour des températures comprises entre $20^{\circ}$ et $30^{\circ}$, températures plus élevées que celles de ses habitats.

L'absence de préférendum de température chez trois espèces est en accord avec l'hypothèse selon laquelle les troglobies confinés tendent à perdre toute réaction à des variations des conditions du milieu qui sont constantes dans les grottes. Il semble que S.bolivari conserve sa sensibilité aux variations de température par suite d'un faible taux d'adaptation au milieu cavernicole. On peut admettre que les réactions de $C$. texensis signifient que cette espèce est issue récemment d'un ancêtre épigé des eaux douces tropicales.

\section{REFERENCES}

AMERICAN PUBLIC HEALTH ASSOC. 1960. Standard methods for the examination of water and wastewater. llth ed. Publ. Off., Am. Public Health Assoc., Inc. New York.

BOLIVAR Y PIELTAIN, C. 1950. Estudio de una Cirolana cavernicola nueva de la región de Valles, San Luis Potosí, México. Ciencia, 10: 211-218.

BOWMAN, TH. E. 1964. Antrolana lira, a new genus and species of troglobitic cirolanid isopod from Madison Cave, Virginia. Int. J. Speleol., 1: 229-236.

BUCHANAN, J.W. 1936. Notes on an American cave flatworm, Sphalloplana percaeca (Packard). Ecol., 17: 194-211.

BULL, E.F., and R.W. MITCHELL. 1972. Temperature and relative humidity responses of two Texas cave-adapted millipedes, Cambala speobia (Cambalida: Cambalidae) and Speodesmus bicornourus (Polydesmida: Vanhoeffeniidae). Int. J. Speleol., 4: 365-393.

DIXON, W.J. (ed.) 1971. BMD, biomedical computer programs. Univ. Calif. Publications in Automatic Computing, No. 2. Univ. Calif. Press, Berkely and Los Angeles. 
EDWARDS, C.L. 1971. The relative humidity and temperature responses of the ricinuleid, Cryptocellus pelaezi (Arachnida). Unpublished MS thesis, Texas Tech Univ., Lubbock.

HOLSINGER, J.R. 1966. Subterranean amphipods of the genus Stygonectes (Gammaridae) from Texas. Am. Midl. Nat., 76: 100-124.

HOLSINGER, J.R. 1967. Systematics, speciation, and distribution of the subterranean amphipoc genus Stygonectes (Gammaridae). Smithsonian Inst., Bull. 259., 152 pp.

JOHNSON, K.W. 1967. Temperature responses of the Mexican blind cave-fishes of the genus Anoptichihys. Unpublished MS thesis, Texas Tech Univ., Lubbock.

MITCHELL, R.W. 1968. New species of Sphalloplana (Turbellaria, Paludicola) from the caves of Texas and a reexamination of the genus Speophila and the family Kenkiidae. Ann. Spéléol., 23: 597-620.

MITCHELL, R.W. 1969. A comparison of temperate and tropical cave communities. Southwestern Nat., 14: 73-88.

MITCHELL, R.W. 1971. Preference responses and tolerances of the troglobitic carabid beetle Rhadine subterranea. Int. J. Speleol., 3: 289-304, pl. 91-96.

MITCHELL, R.W. The cave-adapted flatworms of Texas; systematics, natural history, and responses to light and temperature. In Biology of the Turbellaria, McGraw-Hill, New York. In press

MITCHELL, R.W., and J.R. REDDEL. 1971. The invertebrate fauna of Texas caves, p. 35-90. In E.L. Lundelius and B.H. Slaughter (eds.), Natural history of Texas caves. Gulf Nat. Hist., Dallas, Texas.

MITCHELL, R.W., W.H. RUSSELL, and W.R. ELLIOTT. Zoogeography of the Mexican cave-adapted characin fishes of the genus Astyanax. Special Publ., The Museum, Texas Tech Univ., Lubbock. In press.

POULSON, T.L. 1964. Animals in aquatic environments: animals in caves, p. 749-771. In D.B. Dill (ed.), Handbook of physiology, sect. 4, Adaptation to the environment, ch. 47. Am. Physiol. Soc., Washington.

REDDELL, J.R. 1965. A checklist of the cave fauna of Texas. I. The Invertebrata (exclusive of Insecta). Texas J. Sci., 27: 143-187.

REDDELL, J.R. 1970. A checklist of the cave fauna of Texas. IV. Additional records of Invertebrata (exclusive of Insecta). Texas J. Sci., 31: 389-415.

REDDELL, J.R., and A.R. SMITH. 1965. The caves of Edwards County. Texas Speleol. Survey., $2(5-6): 70 \mathrm{pp}$.

RUSSELL, W.H., and T.H. RAINES. 1967. Caves of the Inter-American Highway. Assoc. Mex., Cave Studies, Bull 1., 126 pp.

SOKAL, R. R., and F. J. ROHLF. 1969. Biometry. W. H. Freeman and Co., San Francisco. SZYMCZKOWSKY, W. 1953. Preferendum termiczne jaskiniswego pajaka Meta menardi Latr. (Argiopidae). Folia Biol. Warzawa, 1: 320.

THINES, G. 1958 Beobachtungen über die Phototaxis und die Thermotaxis des blinden Höhlenfisches, Caecobarbus geertsi (Cyprinidae). Experientia, 14: 1-5.

THINES, G. 1969. L'évolution régressive des poissons cavernicoles et abyssaux. Masson et Cie, Paris.

VANDEL, A. 1964. Biospéologie, la biologie des animaux cavernicoles. Gauthier-Villars, Paris. 